\title{
Türkiye'nin Leishmaniasis Araştırmalarına Katkısı (1980-2019): Bibliyometrik Analiz
}

\section{The Contribution of Turkey on the Research of Leishmaniasis (1980-2019): Bibliometric Analysis}

\author{
Serhat Sirekbasan ${ }^{1 *}$, Tugba Gürkök Tan ${ }^{1}$ \\ Bölümü, Çankırı, Türkiye \\ e-mail: serhatsirekbasan@gmail.com,t.gurkok@gmail.com \\ ORCID: 0000-0001-7967-3539 \\ ORCID: 0000-0003-0599-5628 \\ *Sorumlu yazar/ Corresponding Author: Serhat Sirekbasan \\ Gönderim Tarihi / Received: 20.04.2020 \\ Kabul Tarihi / Accepted: 22.09.2020 \\ DOI: $10.34087 /$ cbusbed.723561
}

${ }^{1}$ Çankırı Karatekin Üniversitesi, Eldivan Sağlık Hizmetleri Meslek Yüksek Okulu, Tıbbi Hizmetler Ve Teknikler

\begin{abstract}
Öz
Giriş ve Amaç: $\mathrm{Bu}$ çalışmada, 40 yıllık bir süre boyunca leishmaniasis araştırmaları hakkında literatürün gözden geçirilmesi ve Türkiye'nin küresel leishmaniasis araştırmalarına artan katkısını değerlendirmek amaçlanmıştır.

Gereç ve Yöntemler: Bibliyometrik veriler Ocak 1980 ile Aralık 2019 arasında Web of Science veritabanında indekslenen tüm leishmaniasis araştırma yayınlarını içermektedir. Çalışmada dil veya belge türü kısıtlaması uygulanmadı. Türkiye için yayın ve araştırma etkisini değerlendirmek amacıyla yazılımın analiz fonksiyonundan ülke olarak "Türkiye" seçilerek bu alanda yapılan yayınlar konularına ve yıllık sayılarına göre kaydedildi.

Bulgular: Web of Science veri tabanında 1980'den 2019'a kadar leishmaniasis ile ilgili 39373 yayın indekslenmiştir. Bu yayınlardan 541'i Türkiye kaynaklı olarak yayınlanmıştır. Elde edilen yayınların yazım dili analiz edildiğinde İngilizce \%95,7'lik oranla en büyük paya sahiptir. Dünya genelinde Leishmania çalışmalarının coğrafi dağılımı incelendiğinde Amerika Birleşik Devletleri'nin 9396 yayın $(\% 23,86)$ ile birinci sırada yer aldığı saptanmıştır. Türkiye ise yayın sayısı bakımından $541(\% 1,37)$ makale ile 20. sırada yer almaktadır.

Sonuç: Bu çalışma, dünya çapında leishmaniasis ile ilgili araştırmalar hakkında bilgi sunmakta ve Türkiye'nin küresel araştırma çıktılarıyla ilişskisini kıyaslayan yeni bir olanak sağlamaktadır. Bu yenilikçi yaklaşımla elde edilen sonuçlar, mevcut bilimsel değişimleri de ortaya koyacağından ilgili araştırmacıların leishmaniasis çalışmaları hakkında güncel durumunu analiz etmelerine yardımcı olacaktır.

Anahtar kelimeler: Bibliyometrik, Leishmania, Leishmaniasis, Türkiye, Web of Science.
\end{abstract}

\section{Abstract}

Objective: The objective of this study is to review the studies on leishmaniasis since 40 years and to evaluate the increasing contribution of Turkey in terms of the studies on leishmaniasis globally.

Materials and Methods: The literature data included all leishmaniasis research publications in the Web of Science database between January 1980 and December 2019. Language or document type limitations were not used. To evaluate the publication and research effect of Turkey, in the analysis function of the database, "Turkey" was chosen as the country and the publications on this topic were recorded based on their subject areas and yearly counts.

Results: A total of 39373 publications were indexed from 1980 to 2019 in the Web of Science database. Among these publication, 541 were from Turkey. Language analysis of the publications revealed that English had the largest percentage (95.7\%). When the worldwide geographical distribution of studies on leishmaniasis was analyzed, United States of America was the first with 9396 publications (23.86\%). In terms of the number of publications, Turkey ranked 20th with $541(1.37 \%)$ articles.

Conclusion: Thus, this study presents information regarding the worldwide studies on leishmaniasis and provides an opportunity to compare the relationship of Turkey's research output with that of the global one. The results of the 
present study will reveal the current scientific changes and thus help in analyzing the current state of leishmaniasis studies.

Keywords: Bibliometric, Leishmania, Leishmaniasis, Turkey, Web of Science

\section{Introduction}

Leishmaniasis is a vector-borne disease caused by a protozoan parasite from the Leishmania genus. More than 20 Leishmania species are considered human pathogens and transmitted to humans by the bite of female sand flies. It is seen endemically in 98 countries in the world which are mostly low and middle-income. It maintains its importance as a public health problem at the global level [1,2]. The clinical manifestations of leishmaniasis can range from a spontaneous healing skin lesion (cutaneous) to a systemic disease (visceral), depending on the characteristics of the parasite and the effectiveness of the immune response in the host $[3,4]$. Although considerable progress has been made in the diagnosis, treatment and prevention of leishmaniasis in recent years, it seems that leishmaniasis is still one of the most neglected diseases in the world, considering that 350 million people are at risk of developing this disease and 1.5-2 million new cases occur annually [5,6]. The World Health Organization (WHO) emphasizes the importance of efforts to improve human health, and states that national health research systems should be developed. Besides, WHO recommends periodic review to encourage studies in the field of neglected tropical diseases, such as leishmaniasis [7].

According to the official numbers in Turkey, $14587 \mathrm{CL}$ cases and 207 VL cases were detected between 2005 and 2012. Besides, sporadic cases from 39 provinces, especially in our Mediterranean and Aegean provinces have been reported, and there has been a significant increase in leishmaniasis cases in the regions known as the focus of infection [8]. On the other hand, particularly in some endemic areas of Turkey leishmaniasis has become a national problem and began to be detected intensely in the country. This may be due to immigrants entering Syria from the country to escape the ongoing civil war. The number of immigrants has reached about 4 million, which requires a review of possible measures in Turkey.

Bibliometric studies encompass large research communities and construct a relationship between researchers. There are several global bibliometric studies in the literature on various infectious diseases, including medical parasitology [9-11]. In addition, there are limited number of bibliometric studies on leishmaniasis that analyze literature research outcomes both worldwide and country specific [12-15]. Every year a lot of publications about leishmaniasis contribute to the literature.

Due to Turkey's geographical location and climate characteristics there are different types of parasites. However, our country has become one of the world's leading destinations for regular migration in recent years, and more importantly, this increases the risk of infectious diseases for both refugees and residents [16-17]. Various researchers draw attention to the dramatic increase in leishmaniasis cases together with immigrants who fled from the civil war in Syria and took refuge in Turkey [1819]. Therefore, it is important to assess the output of scientific research related to Turkey's leishmaniasis in comparison with the world.

This bibliometric study aims to close the gap in the literature by providing an overall picture of research on the development and current status of research on leishmaniasis in the world. Further, this study is conducted for determining how Turkey originated survey contributes to world literature. This will also provide a reference for future research and assist in the planning process for Turkey.

\section{Materials and Methods}

This research was carried out using scientific techniques. The data were obtained from the Thomson Reuters Science Citation Index Web of Science (WoS) online database. The study includes all publications registered with Leishmania in WoS between 1980 and 2019. "Web of Science Core Collection" was chosen from all data options as a search strategy.

In simple search Topic: "leishmania*" and Time span: 1980-2019 was chosen and then from advanced settings all indexes [Science Citation Index Expanded (SCIEXPANDED), Social Sciences Citation Index (SSCI), Arts \& Humanities Citation Index (A\&HCI), Conference Proceedings Citation Index- Science (CPCI-S), Conference Proceedings Citation Index- Social Science \& Humanities (CPCI-SSH), Book Citation IndexScience (BKCI-S), Book Citation Index-Social Sciences \& Humanities (BKCI-SSH), Emerging Sources Citation Index (ESCI)] were accepted. All publications were retrospectively analyzed. No publication language was chosen in the study.

By using the software's "analysis" function all documents of Leishmania research; document types, languages, years of publication, country of origin of the article, name of the journal were evaluated according to a number of qualifications. Later, by selecting "Turkey" as a country, the publications made in this field, and the annual number was recorded according to subjects.

Word Cloud (https://www.wordclouds.com) was used to visualize the keywords of the top 50 most cited publications in WoS and Microsoft Excel tool for data analysis.

\section{Results}

Findings based on the search strategy used in this study showed that 39373 publications were produced in the field of Leishmania at the global level between 1980 and 2019. As can be seen in Figure 1, studies on Leishmania are increasing steadily during the 40 -year periods. In other words, the number of Leishmania articles increased from 160 to 1948 between the years of 1980 and 2019. In Turkey, a total of 541 publications were published in this time period and the highest number was achieved in 2016 


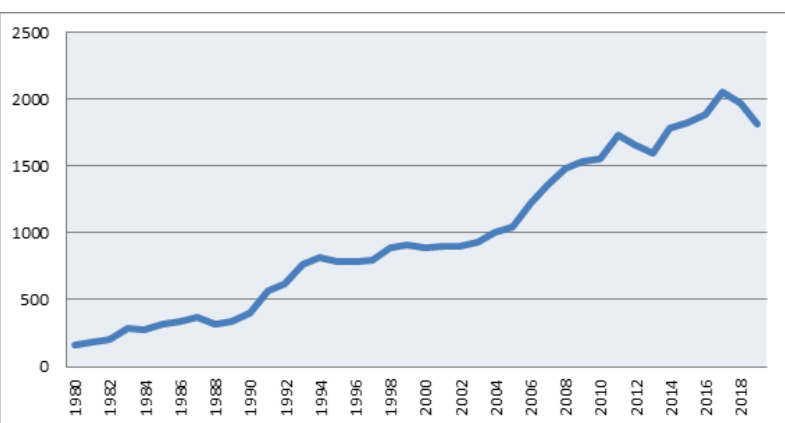

Figure 1. Number of Leishmania publications in Web of Science between 1980 and 2019

with 49 hence, the publications associated with Leishmania, relative increase was also observed.

Global research output demonstrated that according to the document types the original research articles represented by the highest number of publications with 30233 followed by review (3078), meeting abstract (2983), letter (1154), proceeding paper (976), editorial material (708), note (615) and book chapter (418). The remaining documents constituted other type of publications. When we limited the analysis to the publications that have been published in Turkey, we found that the research productivity was 541 during this time period, which was represented the $1.37 \%$ of total scientific research output at global level.

The word cloud created based on the keywords in the first 50 publications that are the most cited among the publications indexed in the field of Leishmania in the WoS database was shown in Figure 2. A word cloud was produced by combining the keywords used in publications. The more frequently the keywords appear within the publications being analyzed, the larger the word appears in the word cloud.

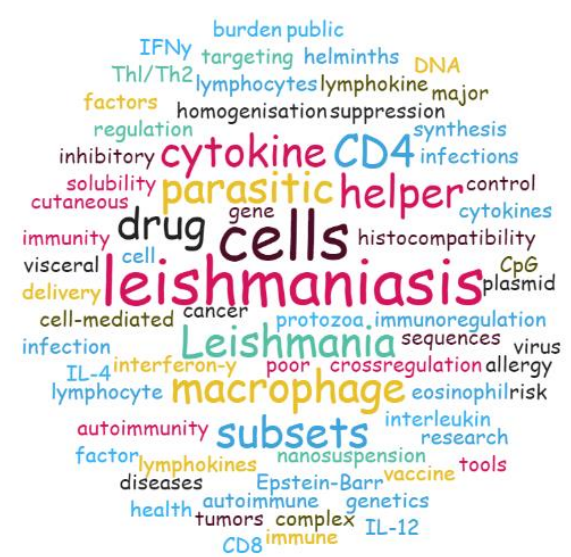

Figure 2. Word cloud of top 50 most cited publications in Leishmania research

\subsection{Language analysis of Leishmania publications}

English was the dominant language with the rate of 95.67\%. followed by French, (n:560; \%1,42), Spanish (n:402; \%1,02), Portuguese (n:357; \%0,90), German (n:245; \%0,62), Russian (n:46; \%0,12), Turkish (n:37; $\% 0,09)$, Italian (n:24; \%0,06) and others (n:34; \%0,09), respectively. When we analyze the Turkey originated publications it was detected that 499 of them were written in English, 37 in Turkish one in French and the remaining three were written in other different languages.

3.2. Country wise distribution of publications

Totally 177 countries contributed to the Leishmania literature worldwide. It was observed that among these 177 countries, United States of America (USA) got the first position in the rank by highest number of publication (n:9396 ; 23.86\%) and the following countries were Brazil (n:7572; 19.23\%) and India (n:3437; 8.73\%) throughout this study period, respectively. However, Turkey ranked 20th by 541 (1.37\%) publications (Figure 3).

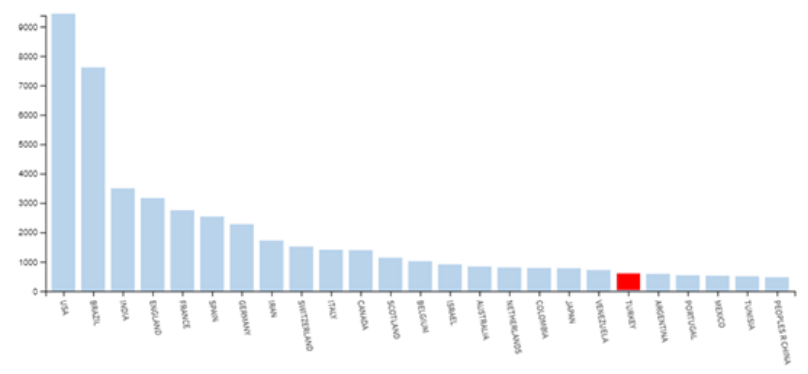

Figure 3. Comparative rankings between Turkey and top 25 countries in Leishmania research

\subsection{Analysis of Leishmania Publications According to Journals and Impact Factors}

WoS online database was used to analyze the journal names of all publications and it was observed that 3412 publications were published. In the Table 1, names of the first 10 journals along with their number of publications and impact factors were given. The top 10 journals that published at global level, constituted $20.66 \%$ of the literature of leishmaniasis. Approximately half of the literature is distributed across 64 sources and the remaining half is distributed in 3348 sources. Besides, 1507 sources have published only one document about Leishmania. The three journals with the highest number of publications were "American Journal of Tropical Medicine and Hygiene" (n:1427), "Molecular and Biochemical Parasitology" (n:913) and "Journal of Immunology" (n:912). The first three journals that published the articles from Turkey were "American Journal of Tropical Medicine and Hygiene" (n:21), "Mikrobiyoloji Bulteni" (n:20) and "Acta Tropica" (n:18) (Table 2).

\section{Discussion}

According to WHO's epidemiological data for 2017, more than 1 billion people are reported to be at risk of leishmaniasis. The disease is often characterized by large outbreaks in densely populated cities, especially in war and conflict zones, refugee camps, and where there are large-scale migration movements [20] hence; leishmaniasis has been a global public health problem for a long time.

Due to the civil war in Syria, about seven million people forced to migrate to the world's various countries, especially Turkey. Leishmaniasis has become a global public health problem because of the outbreaks among 
Table 1. List of top 10 journals related to leishmaniasis research

\begin{tabular}{lcc}
\hline Journal & Number of & IF $^{\mathbf{a}}$ \\
& documents (\%) \\
\hline American Journal of Tropical Medicine and Hygiene & $1427(3,62)$ & 2,315 \\
Molecular and Biochemical Parasitology & $913(2,32)$ & 2,158 \\
Journal of Immunology & $913(2,32)$ & 4,718 \\
Transactions of The Royal Society of Tropical Medicine and Hygiene & $895(2,27)$ & 2,307 \\
Plos Neglected Tropical Diseases & $845(2,15)$ & 4,487 \\
Experimental Parasitology & $712(1,81)$ & 1,719 \\
Infection and Immunity & $669(1,70)$ & 3,160 \\
Acta Tropica & $635(1,61)$ & 2,629 \\
Memórias do Instituto Oswaldo Cruz & $604(1,53)$ & 2,368 \\
Plos One & $556(1,41)$ & 2,776 \\
\hline
\end{tabular}

Impact factors (IF) based on Journal Citation Reports (JCR) 2019 from Clarivate Analytics

Table 2. List of top 10 journals published related to leishmaniasis research from Turkey

\section{Number of documents}

Journal

\begin{tabular}{lcc}
\hline American Journal of Tropical Medicine and Hygiene & $21(3,88)$ & 2,315 \\
Mikrobiyoloji Bulteni & $20(3,70)$ & 0,446 \\
Acta Tropica & $18(3,33)$ & 2,629 \\
Journal of Vector Ecology & $17(3,14)$ & 1,437 \\
International Journal of Dermatology & $13(2,40)$ & 1,794 \\
Parasites Vectors & $13(2,40)$ & 3,031 \\
Plos Neglected Tropical Diseases & $11(2,03)$ \\
Journal of Medical Entomology & $10(1,85)$ \\
Parasitology Research & $9(1,66)$ & 4,487 \\
Ankara Universitesi Veteriner Fakultesi Dergisi & $8(1,48)$ & 2,067 \\
\hline
\end{tabular}

Impact factors (IF) based on Journal Citation Reports (JCR) 2019 from Clarivate Analytics

the Syrian refugee community, as well as new cases that occur every year [21]. In this study, a systematic search was made with the data obtained from WoS. The worldwide situation of scientific researches about leishmaniasis was examined and compared with Turkey. Our study quantitatively described the volume of research on leishmaniasis both in the world and in Turkey, between 1980-2019 time periods. Analyses have revealed an increase in the number of publications on leishmaniasis over this period. This increase continued to rise relatively until 2017 and then showed a decreased pattern. It can be thought that the fact that the scientific research rates have decreased worldwide after 2017 is due to the gains made as a result of the intense efforts of WHO regarding control and prevention activities. Furthermore, the medicinal drug discoveries might cause a decrease in the leishmaniasis and therefore the publications. However, the problem is drug resistant Leishmania strains are occurring which might promote new research on leishmaniasis. 
In this time period, there has been a general rise in the Leishmania publications in Turkey as well as a sharp increase in 2005 and 2015. This may have been due to the difficulties in drug supply in our country in 2004 and its increase with the number of 4187 cases due to insufficient attention to cutaneous leishmaniasis. The increase in 2015 can be explained by the fact that the war in neighboring countries strengthened the risk factors that caused the disease to spread among people and turned the disease into a regional threat, and also increased the number of cases of leishmaniasis originating from abroad [21-23]. As in other research areas, most of the leading researchers in the field of Leishmania are in G7 countries (Canada, France, Germany, Italy, Japan, UK and USA), which have the largest economy in the world, and also in BRIC (Brazil, Russia, India and China) countries which have grown at high speed in recent years. These countries are promoting their research and development investments to be a part of the world class research group. It has also been suggested that the economic power of a nation affects research output [24-26]. Therefore, the scientific productivity of low-income countries in research areas is similarly low. On the other hand, why countries such as India and Iran are in the top 10 in terms of contribution to the literature can be explained by the fact that leishmaniasis disease is endemic in these countries.

Different approaches have been used to measure the innovative performance, capacity and potential of countries. To identify a group of countries with effective scientific programs, Innovative Developing CountriesIDCs concept was developed in 2005. According to the methodology adopted in this approach, when the 25 most innovative countries are listed, although not belong to the category of high-income economy, it should be noted that a few countries take part such as Turkey, in recent years. This suggests that some developing countries have mobilized the scientific and technological workforce to address the main health problems affecting their populations [27].

\section{Conclusion}

In this study, we examined the last 40 years of leishmaniasis at the global level and revealed Turkey's contribution to the literature. An increase in the number of publications on Leishmania has been observed over the years. Globally, Turkey contributed to $1.37 \%$ of total 39373 publications and was ranked 20th. As a result, the data presented in the study provide a clear picture of the increase in publications in the field of Leishmania and can help relevant researchers analyze the current state of their leishmaniasis studies.

\section{References}

1. Alvar, J, Vélez, I.D, Bern, C, Herrero, M, Desjeux, P, Cano, J, Jannin J, den Boer, M, WHO Leishmaniasis Control Team, Leishmaniasis worldwide and global estimates of its incidence, PLoS One, 2012, 7 , e35671.

2. Salam, N, Al-Shaqha, W.M, Azzi, A, Leishmaniasis in the middle East: incidence and epidemiology, PLoS Neglected Tropical Diseases, 2014, 8(10), e3208.
3. Torres-Guerrero, E, Quintanilla-Cedillo, M.R, Ruiz-Esmenjaud, J, Arenas, R, Leishmaniasis: a review, F1000Res, 2017, 6, 750.

4. Handler, M.Z, Patel, P.A, Kapila, R, Al-Qubati, Y, Schwartz, R.A Cutaneous and mucocutaneous leishmaniasis: Clinical perspectives, Journal of the American Academy of Dermatology, 2015, 73(6), 897908.

5. den Boer, M.L, Alvar, J, Davidson, R.N, Ritmeijer, K, Balasegaram, M, Developments in the treatment of visceral leishmaniasis, Expert Opinion on Emerging Drugs, 2009, 14(3), 395-410.

6. den Boer, M, Argaw, D, Jannin, J, Alvar, J, Leishmaniasis impact and treatment Access, Clinical Microbiology and Infection, 2011, 17(10), 1471-1477.

7.Hanney, S.R, González-Block, M.A, Organising health research systems as a key to improving health: the World Health Report 2013 and how to make further progress, Health Research Policy and Systems, 2013, 11, 47.

8.Basualdo, J.A, Grenóvero, M.S, Bertucci, E, Molina, N.B, Bibliometric analysis of scientific literature on intestinal parasites in Argentina during the period 1985-2014, Revista Argentina de Microbiología, 2016, 48(2), 171-179.

9. Ortiz-Martínez, Y, Assessing worldwide research productivity on tuberculosis over a 40-year period: A bibliometric analysis, Indian Journal of Tuberculosis, 2017, 64(3), 235-236.

10. Al-Jabi, S.W, Global research trends in West Nile virus from 1943 to 2016: a bibliometric analysis, Global Health, 2017, 13(1), 55.

11. Ramos, J.M, González-Alcaide, G, Bolaños-Pizarro, M, Bibliometric analysis of leishmaniasis research in Medline (1945-2010), Parasites \& Vectors, 2013, 6, 55.

12. Al-Jabi, S.W, Arab world's growing contribution to global leishmaniasis research (1998-2017): a bibliometric study, BMC Public Health, 2019, 19(1), 625.

13. Soosaraei, M, Khasseh, A.A, Fakhar, M, Hezarjaribi, H.Z, A decade bibliometric analysis of global research on leishmaniasis in Web of Science database, Annals of Medicine and Surgery, 2018, 26, 30-37.

14. Ram, S, India's Contribution and Research Impact in Leishmaniasis Research: A Bibliometric Analysis, Journal of Scientometric Research, 2018, 7(1), 38-44.

15. Değerli, S, Özçelik, S, Çeliksöz, A, Cumhuriyet Üniversitesi Tıp Fakültesi parazitoloji laboratuvarına başvuran hastalarda bağırsak parazitlerinin dağılımı, Türkiye Parazitoloji Dergisi, 2005, 29, 116119.

16. Ekmekci, P.E, Syrian Refugees, Health and Migration Legislation in Turkey, Journal of Immigrant and Minority Health, 2017, 19(6), 1434-1441.

17. Salman, I.S, Vural, A, Unver, A, Saçar, S, Suriye İç Savaşı Sonrası Nizip'te Kutanöz Leyşmanyazis Olguları, Mikrobiyoloji Bülteni, 2014, 48(1), 106-113.

18. Sezen, İ, Turan, M, Kaya, A.A, Türkiye'deki Suriyeli Misafirler ve İlişkilendirilen Bulaşıcı Hastalıklar, Gümüşhane Üniversitesi Sağlık Bilimleri Dergisi, 2018, 7(4), 119-127.

19. World Health Organization, Leishmaniasis, https://www.who.int/leishmaniasis/en/, (accessed 13.02.2020).

20. United Nations High Commissioner for Refugees, UNHCR Turkey Stats, https://www.unhcr.org/tr/en/unhcr-turkey-stats, (accessed 13.02.2020).

21. Gürel, M.S, Yeşilova, Y, Olgen, M.K, Ozbel, Y, Türkiye'de Kutanöz Leishmaniasisin Durumu, Türkiye Parazitoloji Dergisi, 2012, 36(2), 121-129.

22. World Health Organization, Leishmaniasis in the European Region, a WHO consultative intercountry meeting; 17-19 November 2009, Istanbul, Turkey.

23. World Health Organization, Global Health Observatory data repository.

http://apps.who.int/gho/data/node.main.NTDLEISH?lang=en, (accessed 15.02.2020).

24. Bornmann, L, Wagner, C, Leydesdorff, L, BRICS countries and scientific excellence: A bibliometric analysis of most frequently cited papers, Journal of the Association for Information Science and Technology, 2015, 66(7), 1507-1513.

25. Liu, X, Zhang, L, Hong, S, Global biodiversity research during 19002009: a bibliometric analysis, Biodiversity and Conservation, 2011, $20,807$.

26. Zyoud, S.H, Global toxocariasis research trends from 1932 to 2015: a bibliometric analysis, Health Research Policy and Systems, 2017, $15(1), 14$ 
27. Vasconcellos, A.G, Fonseca e Fonseca, B.P, Morel, C.M, Revisiting the concept of Innovative Developing Countries (IDCs) for its relevance to health innovation and neglected tropical diseases and for the prevention and control of epidemics, PLoS Neglected Tropical Diseases, 2018, 12(7), e0006469.

http://edergi.cbu.edu.tr/ojs/index.php/cbusbed isimli yazarın CBU-SBED başlıklı eseri bu Creative Commons Alınt1-Gayriticari4.0 Uluslararas1 Lisans1 ile lisanslanmıştır.

(c) (7) \& 